\title{
Using Micropile to Retrofit of Tilting Building Rested on Alluvium Deposits: Case Study of Inclined Elven Stories Building at Egyptian Delta
}

\author{
Ahmed Elgamal ${ }^{1}$ \\ ${ }^{1}$ Mansoura Higher Institute of Engineering and Technology \\ Mansoura Damietta Road, Mansoura, Egypt \\ Aelgamal@mc.edu.eg
}

\begin{abstract}
Although Egypt has a wide area, nearly 1,000,000 m2, the population concentrates at Delta of the River Nile. Recently, no space for horizontal expansions, so the tall buildings are commonly used to recover the demands. The demonstrated topsoil of Nile Delta is a transported alluvium deposit; high plasticity clay and high compressibility silt; which considered problematic soils. Many buildings in Egypt have no accurate soil investigation programs, so many geotechnical problems appear during and after the construction. The most common geotechnical problem is tilting of structures which make them not serviceable and cause damages for surrounding buildings. Elven stories building has tilted after nearly ten years of its construction. The building has constructed at El-Mahalla El-Kubra city which locates in the middle of Delta Zone. In this research, the micropile technique used to prevent more tilting of the eleven stories building without any harmful effects on surrounding buildings. This technique is not a usual solution for same problems in Egypt, but it seems like an effective and suitable for such constructions in town centers as no space for large drilling machine.
\end{abstract}

Keywords: Micropiles, Soft Clay, Tilting Building, Egyptian Delta, Alluvium Deposits.

\section{Introduction}

Many researches interest in studying the relationship between Egyptian geographic and its geology. According to the most famous classification [1], divides Egypt into Nile Valley, Delta, Eastern Desert, Western Desert, and the Sinai Peninsula. The Nile Delta is the most massive and crucial depositional complex in the Mediterranean basin.

Nowadays around the Nile Valley, most of the tall buildings deal with alluviums deposits [2]. The Nile Delta subdivides into southern, middle, and northern zones which generally characterized by coarse sediments (i.e., sand), finer sediments, and finest sediments, respectively [3]. The main formation of the sediments is clayey to silty clay deposits that widely distributed along the Nile Delta. The thickness of these sediments ranges from $1.00 \mathrm{~m}$ at the south part to more than 15.00 $\mathrm{m}$ at the northern side [4]. The Nile Delta deposits mainly consist of about $0.3 \%$ gravel, $5 \%$ sand, $51.5 \%$ silt, and $42.2 \%$ clay. The average shrinkage limit and plasticity indexes are $11 \%$ and $23.4 \%$, respectively. Also, the free swelling index ranges from $40 \%$ to $75 \%$ [4].

Figure 1 shows the sitemap of the understudying building. It locates in the middle zone of the Nile Delta where the finer sediments (i.e., clay and silt). This area described by [5] as Nile mud deposits of flood basin to clay, silt, and sand.

A magic solution, the micropiles have grown to use as supports of foundations, slopes reinforcements, and to support the shoring systems in case of deep excavations. Micropiles are widely used all over the world to retrofit the tilting buildings and to reinforce the weak soils [6]. 


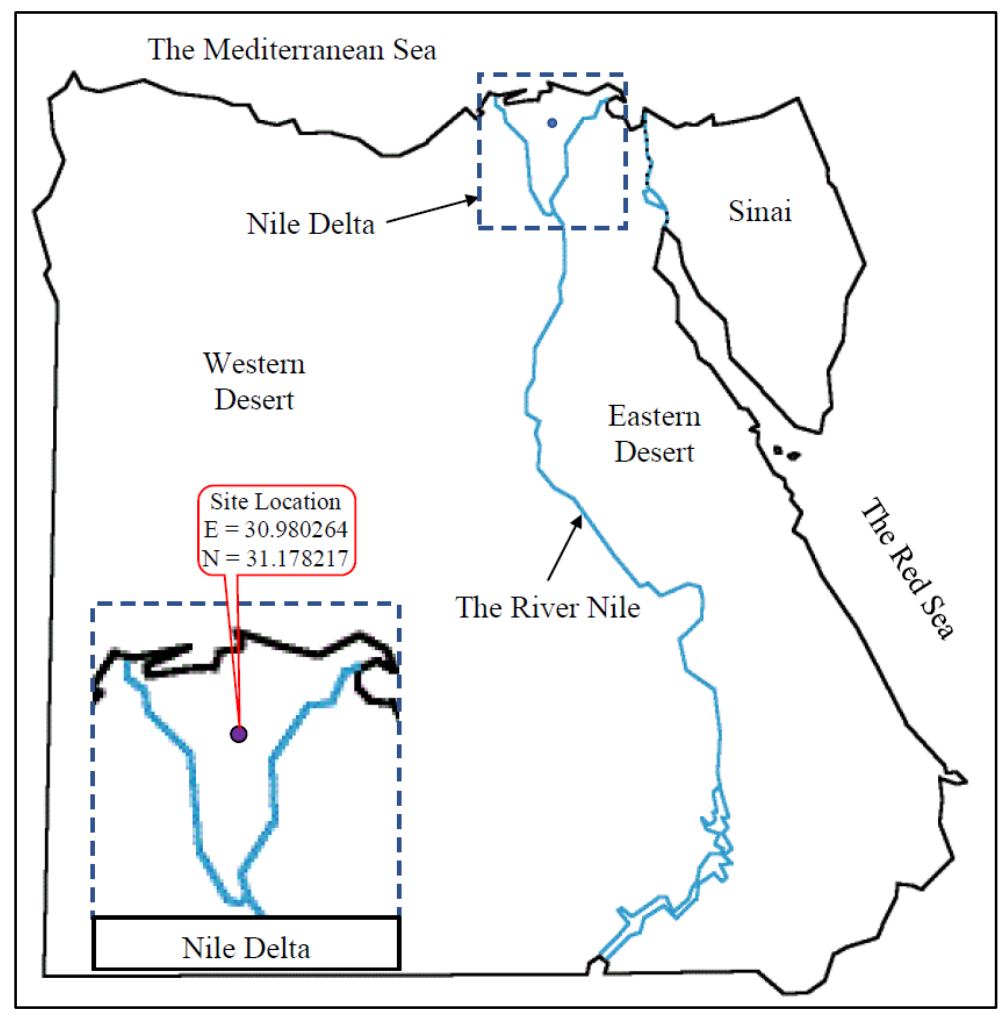

Fig. 1: Sitemap of the understudying building (Source: Google map).

\section{Problem Statement}

The typical damage of the buildings in the studied area (i.e., El-Mahalla El-Kubra) limits in visible $45^{\circ}$ inclined wall cracks accompanied by others in the structural elements. In some cases, a tilt and distortion of the entire building occur. The tilt of some buildings reached a ratio of $1 \mathrm{H}: 50 \mathrm{~V}$, which exceeds the acceptable range provided in the Egyptian code of practice [7] that states allowable tilt is $1 \mathrm{H}: 150 \mathrm{~V}$.

The depth of the groundwater table (GWT) within the zone under study is shallow and fluctuates between 1.5 to 3.0 meters below ground surface. The soft clays in the Nile Delta considered high plasticity which could be the primary reason for many tilts and distortions that occur to the buildings. The illegal construction of the residential buildings grows the problem of soil settlement and buildings tilting during the last few years. The construction of these buildings completes without having a license or permission from the appropriate governmental authorities.

This research introduces a case history of eleven stories residential building constructed over a deep soft clay layer at El-Mahalla El-Kubra city, Egypt. After nearly ten years of construction, noticeable inclination and cracks in the building were observed, causing several serviceability problems. The cracks observed after removal of one of the neighboring buildings. Micropiles recovery system, connected to the existing raft foundation, was used to prevent the building from continue tilting. After completing the retrofit installation, the tilt of the building has monitored over a oneyear period, and it determined that the tilting has completely stopped after 20 days of performing the micropiles.

\section{Building Description}

The structure locates close to the center of the city of El-Mahalla El-Kubra. The construction of the building began in January 2006 and completed in January 2008 with a total area of about $145 \mathrm{~m} 2$ and consists of a commercial ground floor and ten typical residential stories. Figure 2 shows the layout of the inclined building. 


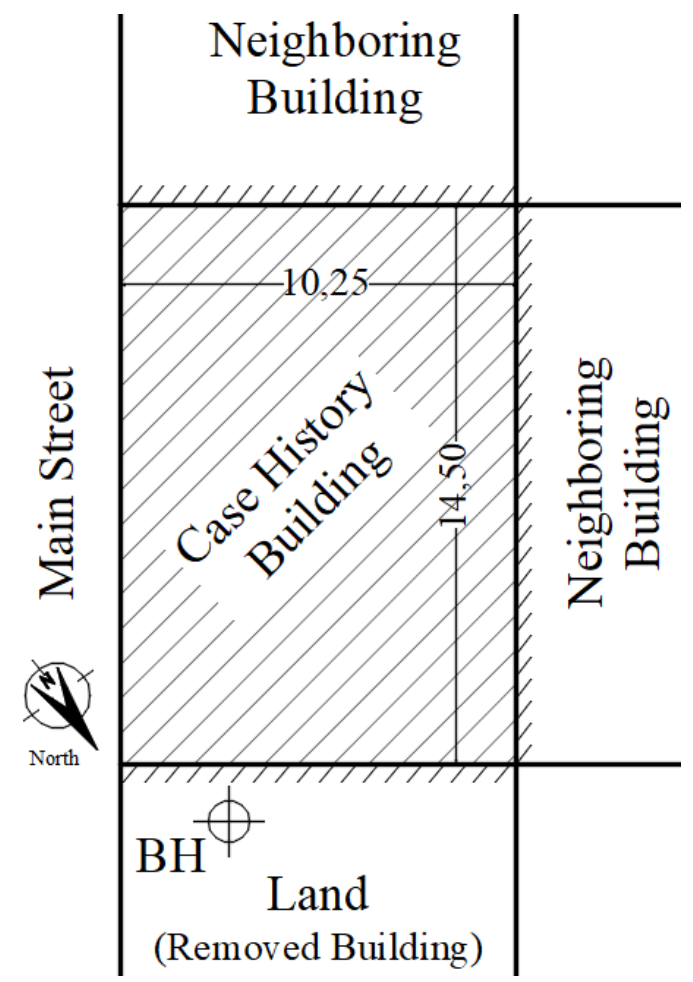

Fig. 2: Layout of the inclined building and the location of the borehole.

The structural system of the ground and typical floors consists of $200 \mathrm{~mm}$ flat slabs with marginal beams supported on a $1000 \mathrm{~mm}$ thick reinforced concrete raft. The foundation level is $2.00 \mathrm{~m}$ below the ground surface. The original and retrofitted design of the foundation system for the building shown in Fig. 3.

After the removing of the existing neighboring structure (i.e., the land on the northern side, see Fig. 2), hair cracks had observed in the wall beside the removed building. The removed building consisted of 3 floors (reinforced concrete slabs carried by bearing walls) rested on a 400-mm wide, and 1-m height of plain concrete tie beam overlies about 200 to $250 \mathrm{~mm}$ plain concrete. After nearly 30 days of building removal, hair cracks were observed getting more broader and more extended towards the removed building. The building understudying begins tilting.

\section{Soil Investigation Program}

The geotechnical and physical properties of the subsurface soil of the site understudy are determined using field and laboratory tests. The bore-hole (BH) located as shown in Fig. 2 because of the constraints in the site (i.e., the unconfirmed public facilities that may impede the drilling of the bore-holes). The following program has carried out to investigate the soil of the site:

1. A bore-hole $(\mathrm{BH})$ was drilled mechanically with a depth of 30 meters from the natural surface very close to the tilted building (Fig. 2).

2. Soil samples extracted every $1.00 \mathrm{~m}$ and at any change in soil nature. The undisturbed samples well-coated with wax according to the requirements of the Egyptian Code of Soil Mechanics and Design and Implementation of Foundations No. 2022001 Edition 2007.

3. The standard penetration test (SPT) was carried out at various depths, especially the sand layers, and the test was carried out according to the requirements of the Egyptian Code and ASTM D1586 - 11 by using a mandrel weighing $140 \mathrm{lbs}$. to fall $75 \mathrm{~cm}$ in order to determine the number of blows to penetrate the soil by $300 \mathrm{~mm}$. The sub-soil internal friction angles are obtained using [8] and [9] correlations as listed in Table 1. 
4. The levels of groundwater monitored at the start and the end of the work of the sumps and a soil sample located at a depth of $2.10 \mathrm{~m}$ below ground level taken for chemical analysis.

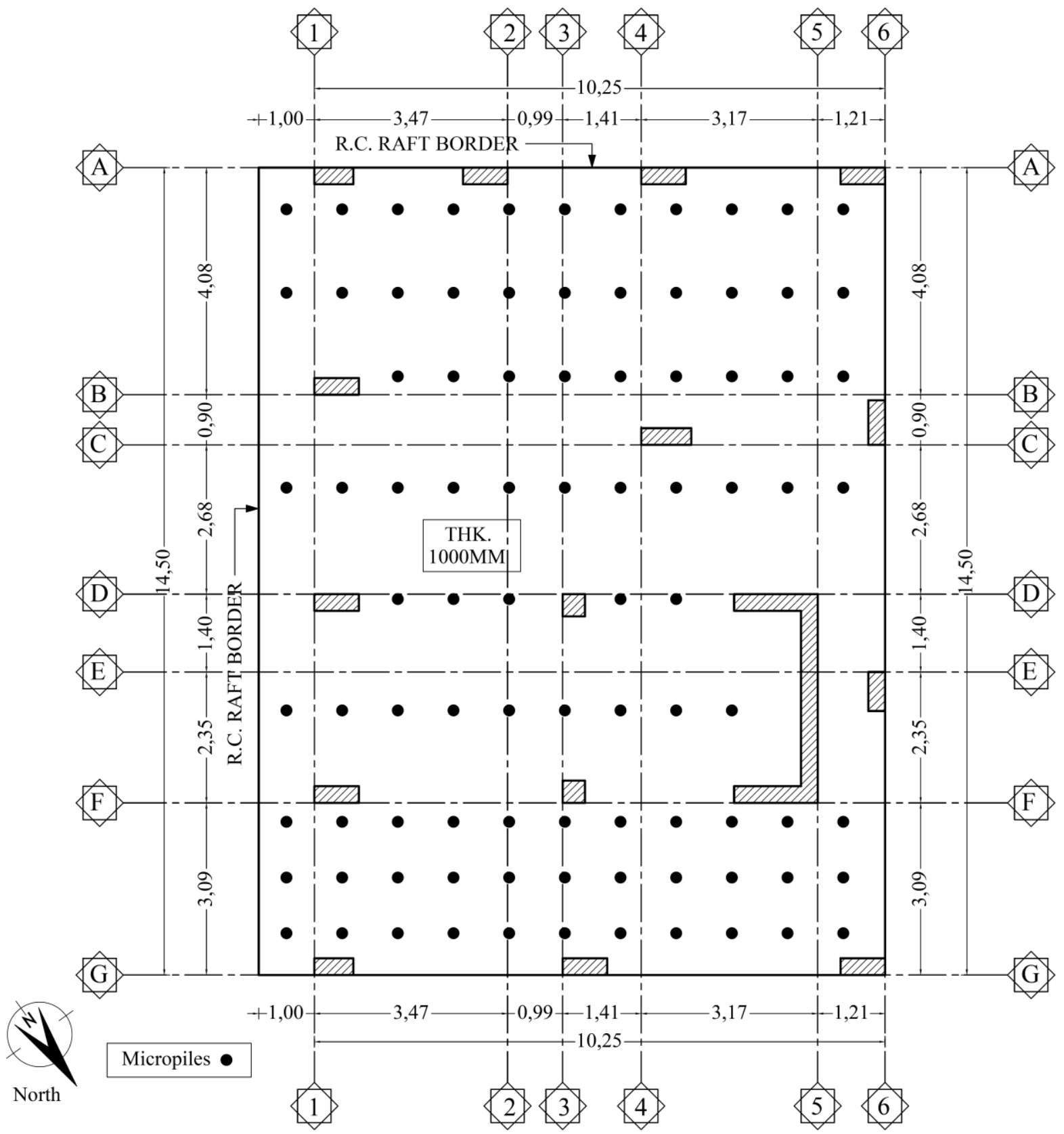

Fig. 3: The layout of the original and new foundations for the case study building.

The subsurface mainly consists of a $2.00 \mathrm{~m}$ thick layer of fill overlies a $3.00 \mathrm{~m}$ thick sandy silt. Below that, a 9.30 $\mathrm{m}$ thick layer of soft to medium, silty sand which underlined by a $1.90 \mathrm{~m}$ thick layer of medium dense to loose sand. A medium dense to dense sandy layer encountered from level (-18.60) to the end of the soil profile. 
Table 1: General soil profile (Bore Hole BH).

\begin{tabular}{|c|c|c|c|c|c|c|c|}
\hline \multirow{2}{*}{ Layer } & \multirow{2}{*}{ } & \multirow{2}{*}{$\begin{array}{c}\text { Top } \\
\text { Level } \\
(\mathbf{m})\end{array}$} & \multirow{2}{*}{$\begin{array}{c}\text { Saturated } \\
\text { Unit } \\
\text { Weight } \\
\gamma\left(\mathbf{k N} / \mathbf{m}^{3}\right)\end{array}$} & \multirow{2}{*}{$\begin{array}{c}\varphi \\
\text { (Degree) }\end{array}$} & \multicolumn{2}{|c|}{$\begin{array}{l}\text { Atterberg } \\
\text { Limits }\end{array}$} & \multirow{2}{*}{$\begin{array}{l}\text { Undrained } \\
\text { shear } \\
\text { strength, } \mathbf{S}_{\mathbf{u}} \\
\left(\mathbf{k N} / \mathbf{m}^{2}\right)\end{array}$} \\
\hline & & & & & $\begin{array}{l}\text { L.L. } \\
(\%)\end{array}$ & $\begin{array}{l}\text { P.L. } \\
\text { (\%) }\end{array}$ & \\
\hline Fill & 3 & 0.00 & 15.0 & - & - & - & - \\
\hline Sandy silt & & -2.00 & 17.0 & 20 & 40 & 6 & 25 \\
\hline $\begin{array}{l}\text { Soft to medium, } \\
\text { silty clay }\end{array}$ & $2 \%$ & -5.00 & 17.8 & - & 45 & 22 & $40-90$ \\
\hline $\begin{array}{l}\text { Medium dense to } \\
\text { loose sand }\end{array}$ & & -14.30 & 18.0 & 38 & - & - & - \\
\hline Stiff clay & I & -16.20 & 18.2 & - & 44 & 21 & 115 \\
\hline $\begin{array}{l}\text { Medium dense to } \\
\text { dense sand }\end{array}$ & & $\begin{array}{l}-18.60 \\
-30.00\end{array}$ & 18.5 & 40 & - & - & End of Boring \\
\hline
\end{tabular}

The samples extracted from the bore-holes have examined outwardly and in the laboratory. Thus, the longitudinal section can schematically represent as shown in Table 1. In accordance with the requirements of the Egyptian Code and ASTM D1586 - 11, disturbed and undisturbed soil samples were collected for laboratory testing which included unconfined compression tests using pocket penetrometer, Atterberg limits (Table 1), soil gradation (Fig. 4 and Table 2), and 1-D consolidation tests (Fig. 5). Also, samples of the groundwater extracted from the site of the bore-holes were analyzed to determine the percentage of soluble salts of sulfur Chlorides, hydrogen sulfide. 


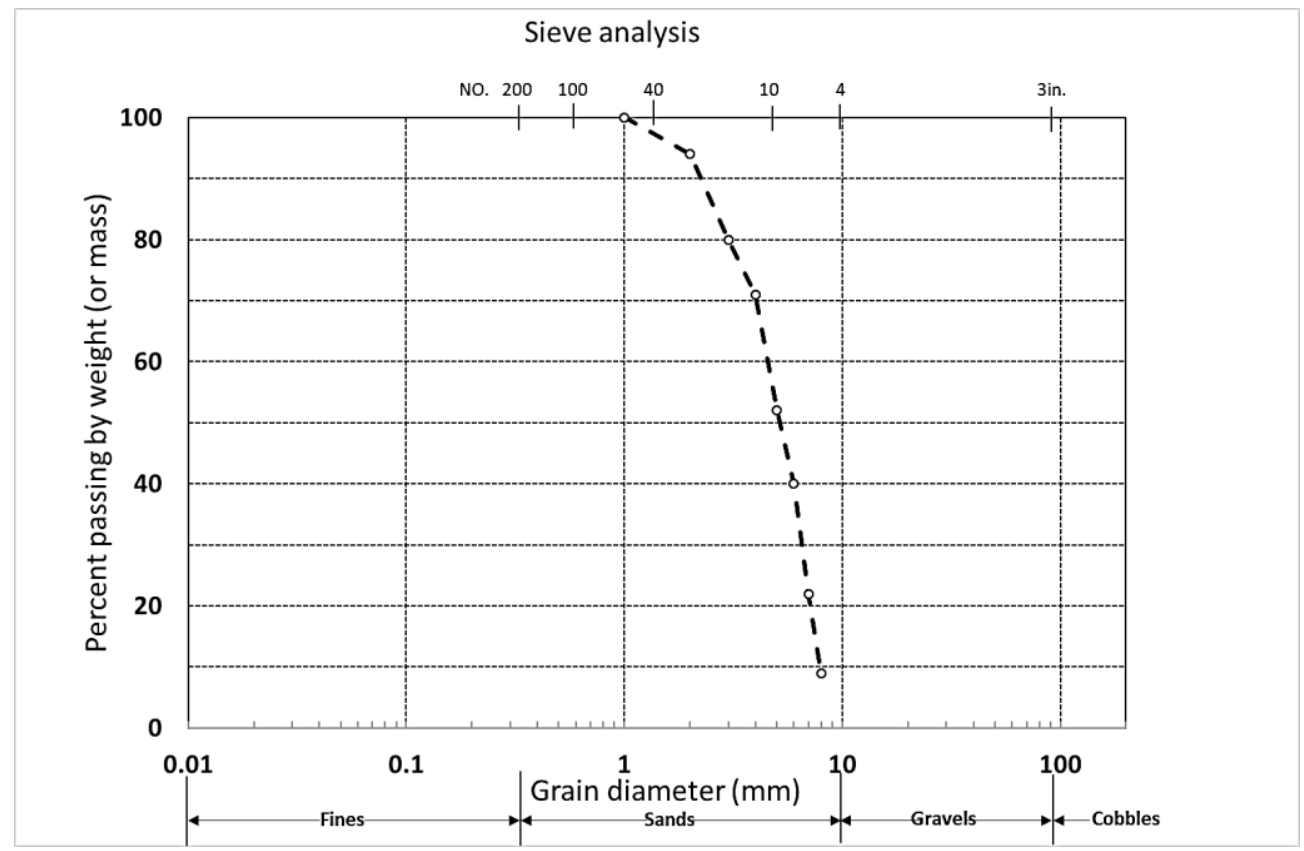

Fig. 4: Particle size distribution of sand at depth $21.00 \mathrm{~m}$.

Table 2: Physical properties of sand.

\begin{tabular}{|l|c|}
\hline \multicolumn{1}{|c|}{ Property Description } & Value \\
\hline Max. void ratio & 0.843 \\
\hline Min. void ratio & 0.617 \\
\hline Max. dry density, $\mathrm{Mg} / \mathrm{m}^{3}$ & 1.639 \\
\hline Min. dry density, $\mathrm{Mg} / \mathrm{m}^{3}$ & 1.438 \\
\hline Specific gravity & 2.65 \\
\hline Water content, \% & 0.08 \\
\hline Average particle size, $\mathrm{mm}$ & 0.595 \\
\hline Effective particle size, $\mathrm{mm}$ & 0.443 \\
\hline Uniformity coefficient & 1.402 \\
\hline Coefficient of curvature & 0.912 \\
\hline
\end{tabular}




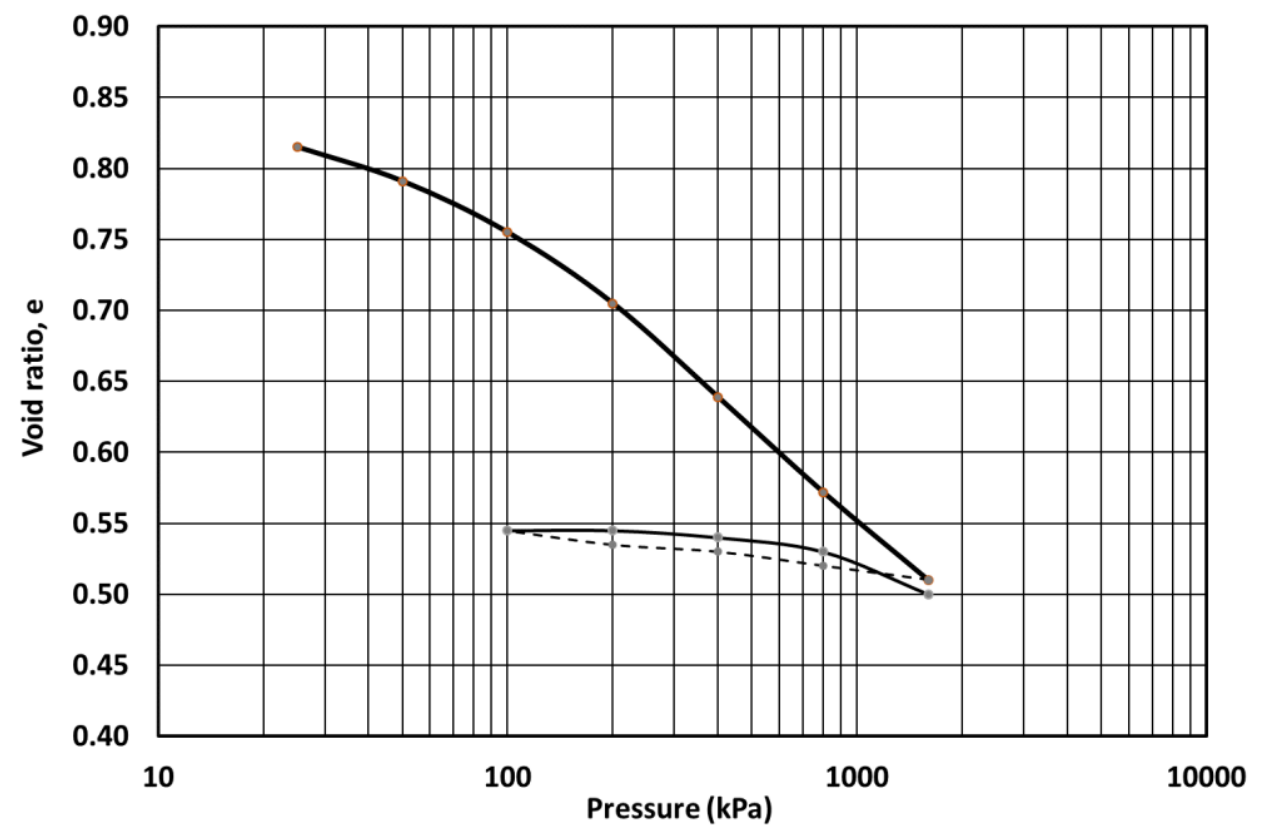

Fig. 5: Oedometer test.

\section{Micropiles type Selection}

Micropiles are used for seismic retrofit applications and can install at any angle according to the mechanism of the installation equipment. The design of micropiles considers the philosophy of pile behavior with the surrounding soil and the method of grouting. The axial capacity of the micro-pile, generally, can be obtained from the used steel reinforcement (i.e., structural capacity) and the geotechnically side shear resistance (i.e., geotechnical capacity) [6].

Micropiles are generally classified according to the method of grouting into four types $(\mathrm{A}, \mathrm{B}, \mathrm{C}$, and $\mathrm{D})$ as shown in Table 3. The grouting is used in micropiles to transfer the axial load from the steel reinforcement to the surrounding soil and protect the steel reinforcement from corrosion. Grouting type B1 is used to design the retrofit micropile where the number 1 indicates using mono-bar reinforcement or tube.

Table 3: Micropile classification based on grouting type (after [6]).

\begin{tabular}{|c|c|c|}
\hline Grouting Type & Description & Grout \\
\hline A & Gravity grout only & Sand/cement mortar or neat cement. \\
\hline B & Pressure - grouted through the casing. & Neat cement. \\
\hline C & $\begin{array}{c}\text { Primary grout placed under gravity } \\
\text { head then pressure grouting. }\end{array}$ & Neat cement. \\
\hline D & $\begin{array}{c}\text { Primary grout placed under gravity } \\
\text { head then high-pressure grouting. }\end{array}$ & Neat cemt. \\
\hline
\end{tabular}

A trial $200 \mathrm{~mm}$ diameter and $20 \mathrm{~m}$ length retrofit micropile with the pile properties shown in Table 4 . The grout has applied to the full pile length, and B1 indicates that the grouting is pumped under an excess pressure about $1 \mathrm{MPa}[6] \mathrm{using}$ water/cement ratio equals to 0.4 . The maximum stress based on consideration of grout failure is $600 \mathrm{MPa}$ according to [6], and $360 \mathrm{MPa}$ is the yield strength of the used reinforcement bar. 
Table 4: Utilized micropile properties.

\begin{tabular}{|c|c|c|c|c|}
\hline Diameter (mm) & Length $(\mathbf{m})$ & Reinforcement & Grout & Axial Capacity (kN) \\
\hline 200 & 20 & $18 \mathrm{~mm}$ monobar & B ${ }^{*}$ & 250 \\
\hline
\end{tabular}

* Grout is pumped under 1MPa excess pressure

Equation 1 is recommended by [6] to obtain the allowable structural (PSC) axial capacity of micro-piles.

$$
P_{S c}=0.4 f_{c}^{\prime} A_{\text {grout }}+0.47 f_{y-b a r} A_{b a r}
$$

Where, $f_{c}^{\prime}$ is the unconfined compressive strength of the grout, $A_{\text {grout }}$ is the grout cross-sectional area, $f_{y-b a r}$ is the yield strength of the steel bar, and $A_{b a r}$ is the cross-sectional area of the used reinforcement bar.

The micropile geotechnical capacity $\left(\mathrm{P}_{\mathrm{GC}}\right)$ can be estimated using the following equation.

$$
P_{G C}=\frac{\alpha_{\text {bond }}}{F . S} \pi D_{b} L_{b}
$$

Where, $\alpha_{\text {bond }}$ is the grout to ground ultimate bond strength which equals to $65 \mathrm{kPa}$ according to Table 5-3 in [6], $D_{b}$ is the diameter of the pile, and $L_{b}$ is the bond length. The factor of safety (F.S) is used equal to 2.5 as recommended by [6].

By applying the previous equations, the axial capacity of the retrofit micropile is founded to be $250 \mathrm{kN}$ as the minimum value between Eqs. 1 and 2.

\section{The Monitoring of Building Tilt}

After reviewing all the available (original) construction drawings and monitoring records, visual inspection has performed during the first field visit in May 2017. The significant observations of the visual inspection of the superstructure and the surroundings were as follows:

1. There was a tilt in the building towards the neighboring land (i.e., the removed building) and the main street. The horizontal displacement at the top of the building (about $41.4 \mathrm{~m}$ height above the ground surface) was about $550 \mathrm{~mm}$ towards the main street resulting in an inclination ratio of $1 \mathrm{H}: 75 \mathrm{~V}$. Also, a $250 \mathrm{~mm}$ drift towards the neighboring land with an inclination ratio $1 \mathrm{H}: 165 \mathrm{~V}$.

2. Inclined hairline cracks were detected scattered along the exterior walls of the Building. The excessive differential settlement may be the main reason for these cracks.

Table 5 presents the survey observations conducted before and after retrofit using a total station survey instrument. The results in Table 5 indicates that the repairing system (i.e., micro-piles) is a practical solution to prevent any further tilting of the building rested on alluvium deltaic deposits. The retrofit program started at the end of June 2017 and finished at the start of July 2017. 
Table 5: Vertical displacement observations conducted before and after retrofit.

\begin{tabular}{|c|c|c|c|c|c|c|c|c|c|}
\hline \multicolumn{2}{|c|}{ Date } & $\begin{array}{l}\text { May } \\
2017\end{array}$ & $\begin{array}{l}\text { June } \\
2017\end{array}$ & $\begin{array}{c}\text { July } \\
2017 *\end{array}$ & $\begin{array}{c}\text { August } \\
2017\end{array}$ & $\begin{array}{c}\text { December } \\
2017\end{array}$ & $\begin{array}{l}\text { Jan. } \\
2018\end{array}$ & $\begin{array}{l}\text { Feb. } \\
2018\end{array}$ & $\begin{array}{l}\text { July } \\
2018\end{array}$ \\
\hline \multirow{2}{*}{$\begin{array}{c}\text { Vertical } \\
\text { disp. } \\
(\mathrm{mm})\end{array}$} & $\begin{array}{l}\text { Long } \\
\text { Dir. }\end{array}$ & 40.95 & 43.00 & 43.20 & 43.00 & 43.00 & 43.00 & 43.00 & 43.00 \\
\hline & $\begin{array}{c}\text { Short } \\
\text { Dir. }\end{array}$ & 6.25 & 7.25 & 7.00 & 6.75 & 6.75 & 6.75 & 6.75 & 6.75 \\
\hline
\end{tabular}

* Just after performed of the retrofit system.

\section{Proposed Retrofit System}

After studying and analyzing the geotechnical investigation and structural surveying, it was decided to use the micropiles retrofit system to stop the building in question from continuing tilting. The micropiles have been concentrated in the tilting direction (besides the removed building), and the concentration was reduced backwardly (toward the existing building) as shown in Fig. 3.

A new 400-mm reinforced concrete raft proposed to link between the micropiles and the existing raft. The primary objective behind concentrating the micropiles beside the removed building is to reduce/restrict the amount of the foundation differential settlement. Through a severe iterative process, a total number of 89 micropiles with $200 \mathrm{~mm}$ diameter and $20 \mathrm{~m}$ in length were adequate to satisfy the repairing system (Fig. 3). A cross section of the retrofitted system presented in Fig. 6 shows all details and the connection between the existing raft and the new one.

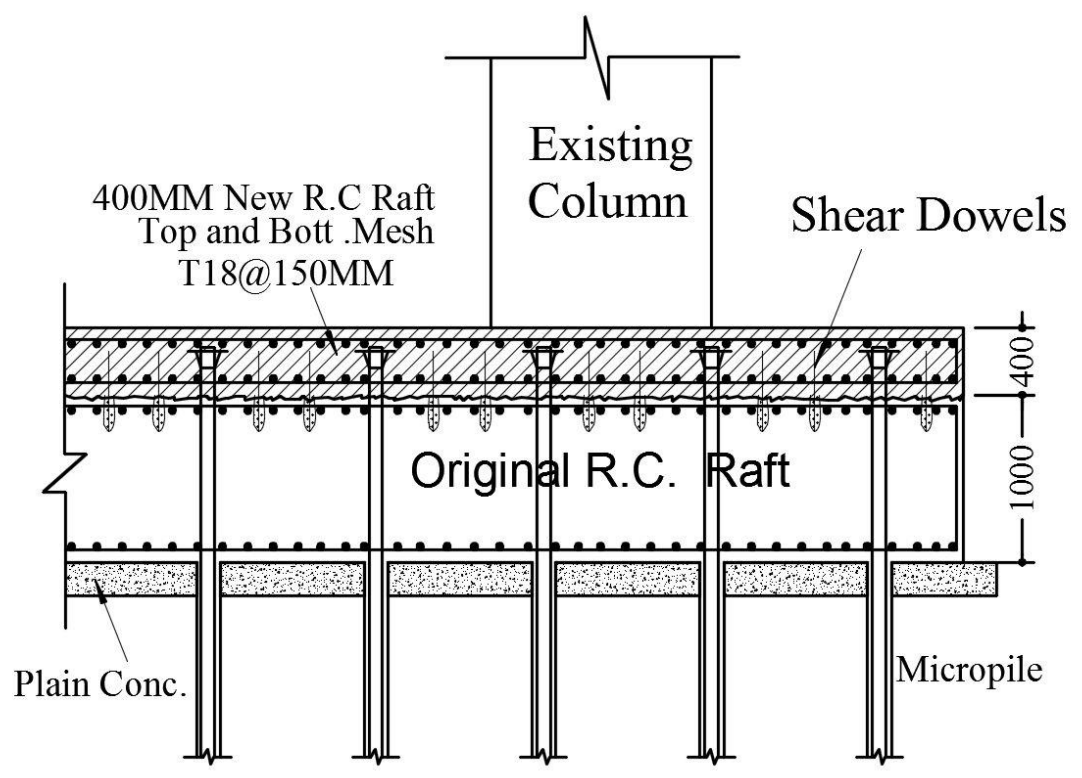

Fig. 6: Cross section in the new micro piled retrofitted raft.

\section{Conclusions}

The micropiles techniques have used in Egypt on a narrow wide. The micropiles are used in this case to prevent a $1 \mathrm{H}: 75 \mathrm{~V}$ inclined elven stories building from continuing tilting. The 89 micropiles network that used success to prevent any further additional tilting. The cost of micropile is high but effective and safe especially in highly concentrated population 
area. The micropiles technique is very effective in such cases in town centers as no space for a large drilling machine. Also, no effects on surrounding structures as they rest on the same problematic soil.

\section{References}

[1] R. Said, The geology of Egypt. Amsterdam-New York: Elsevier, 1962.

[2] M. A. El-Sohby and O. Mazen, "Geology aspects in Cairo subsurface development," in Proceedings of the 11th ICSMFE, 1985, pp. 2401-2405.

[3] Hemdan G., Personality of Egypt, a study in uniqueness of the position. Cairo: Alam El-Kotob, 1980.

[4] A. I. M. Ismail and N. Ryden, "Engineering Geological Characteristics of Soil Materials , East Nile Delta , Egypt," vol. 6, no. 5, pp. 282-287, 2012.

[5] H. E. De Wit and L. V. Stralen, "Preliminary results of the paleogeographical survey," in In E.C.M VAN DEN BRINK (Editor), 1987, pp. 135-139.

[6] FHWA, "Micropile Design and Construction Guidelines," Handbook, no. NHI 132078, p. 456, 2005.

[7] Egyptian Code of Practice (ECP), Soil Mechanics and Foundation Engineering. 2001.

[8] T. F. Wolf, "Pile Capacity Prediction Using Parameter Functions," SCE Geotech. Spec. Publ., vol. 23, pp. 96-106, 1989.

[9] J. H. Schmertmann, J. P. Hartman, and P. R. Brown, "Improved Strain Influence Factor Diagrams," J. Geotech. Eng. Div. Am. Soc. Civ. Eng., vol. 104, no. GT8, pp. 1131-1135, 1978. 